


\section{„A FÜST ELSZÁlL, A PROBLÉMA MARAD”- A DOHÁNYZÁS TÁRSADALMI, GAZDASÁGI HATÁSAI}

'SMOKE IT, FORGET IT, BUT ALWAYS REGRET IT.' -

THE ECONOMIC AND SOCIAL IMPACTS OF TOBACCO SMOKING

FENYVESI Éva - POLÁK-WELDON Réka

Kulcsszavak: szenvedélybetegségek, dohányzás, gazdasági hatékonyság, adózás, dohányzás elleni küzdelem

Keywords: addictive disorders, tobacco smoking, economic productivity, taxation, fight against smoking

JEL kód: E20, I15 


\section{ÖSSZEFOGLALÓ}

A WHO 2016-os Egészségjelentése alapján a dohányzás a második legjelentösebb egészségkockázatú viselkedés. Az Egészségügyi Világszervezet elörejelzései szerint 2025-2050 kö̈ött elöreláthatóan évi tí millió ember hal majd meg dohányzás követkeqtében.

Ezért nem véletlen, bogy szakirodalom széles körben foglalkozik ezzel a jelenséggel. A megközulitések azonban zömében egészségügyi, pszichológia, morális vagy kriminológiai szempontból vizsgálják a kérdést. A különbözó szenvedélybetegségek (addik.tológiai kórképek.) az egyénnek, valamint mikro-, és makrokörnyezetének komoly gazdasági és társadalmi gondot okoznak, mint például az érintett személyek gyógykezelése, a munkaképesség csök.kenése, vagy a sz̨envedélybetegségekkel összefüggö családi tragédiák.

Tanulmányunkban a dobánytermékek fogyasztásának hatásait elsösorban közgazdasági szempontból kivánjuk górcsố alá venni. Célunk, hogy az emlitett területeken megkiséreljüke. feltárni ezeknek a termékcsoportoknak a termelésével, forgalmazásával, illetve fogyasztásával kapcsolatosan felmerülö társadalmi, gazdasági károkat és hasznokat. Ez utóbbiakat ritkán emlitik (vagy egyáltalán nem említik), pedig sqámos személy, vállalkozás, sôt maga a társadalom számára a szenvedélybetegségek nemcsak áldozati, hanem haszonelemeket is tartalmaznak.

A cike elsö részében azokat a közgazdasági elméleteket és ezekre épülö kérdéseket, felvetéseket mutatjuk be, amelyek köré e vizsgálatot fel kivánjuk épiteni. Eqután az elérhetö statisqtikai adatok és a különböző" szekunder kutatások alapján megpróbáljuk feltárni a dohánytermékekere vonatkozóan a fogyasztásukból származó társadalmi, gazdasági hasznokat és károkat/ költségeket.

\section{SUMMARY}

As reported by the World Health Statistics 2016 smoking causes every second death in the world. The prediction of the World Health Organisation is that between 2025 and 2050 the number of cumulative deaths from smoking will be around ten million a year.

Smoking is frequently analysed in scientific literature from a health, moral or criminological perspectives, because addictive disorders precipitate and perpetuate far-reaching social problems. Individuals and their families suffer from relationship imbalances or in the worst case, from loss of relatives. Companies experience additional costs resulting from increasing absenteeism and in the long run their financial performance is declining. At the macro-environmental level, it leads to economic and social problems such as the need of expensive health treatments.

This paper intends to examine the economic aspects of the impacts of smoking. Our goal is to reveal the economic and social harm and possible benefits related to the production and trade as well as consumption of tobacco products. The possible benefits linked with tobacco products are 
rarely analysed even though some individuals, businesses and society at large can, in some ways, benefit from them.

In the first part of the article the economic theories and related questions are introduced which provide the theoretical framework for the empirical research. Following the theoretical review, the economic and social benefits, harms, and costs caused by the use of tobacco products are presented based on available statistical data and secondary research.

\section{INTRODUCTION}

There are many different habits of addiction people feel attached throughout their lives. These routines can both improve and deteriorate quality of life by possibly leading to bad habits. Good habits help us through our everyday life but bad ones such as addiction cause damage to the individual. Once addiction is developed, it has additional consequences like the need for an increasing amount of substance to get the same effect. Using a substance regularly has a more intense effect, which leads to addiction. Balzac wrote it once in a novel titled Ferragus: Chief of the Devorants 'There are few passions that will not fail in rectitude in the long run' (Balzac, 1955:43). Addictive disorders are forms of behaviour, which cannot be controlled by the individual. As a result, they are continuously repeated and have a negative impact on the individuals and their environment (Demetrovics \& Balázs, 2014).

In everyday life, addictions often link to alcoholism, smoking and drug use. In reality, addictions are complex illnesses. They can be characterised by the inability to control oneself and with time, the control process is becoming more and more difficult, up to a point where the individual loses all control. The common characteristic of all types of addiction is that there is a strong desire towards the object of the addiction and by fulfilling the desire, the individual feels satisfaction only for a short period of time leading to a repetitive chain of actions. Addiction takes over the thoughts of the individual and instead of getting a boost of energy, it harms the individual (Nemeskéri \& Pankász, 2015).

\section{THEORETICAL BACKGROUND}

There are various types of addiction, but as a whole, two main categories can be distinguished (Nemeskéri \& Pankász, 2015). Chemical dependencies are for example nicotine- and alcohol dependency, caffeine, medications, and the use of 
illegitimate substances. Individual behavioural disorders can take many forms such as gaming, phone and computer addiction, internet addiction, workaholism, shopaholism, kleptomania or pyromania. Sex addiction and codependency disorder are related to inadequacies of interpersonal relationships while eating disorder is a type of behavioural disorder, which manifests itself in constant preoccupation with food. There are some common characteristics of all addictions (Demetrovics \& Balázs, 2014; Füredi et al., 2015). There is a continuous desire to repeat a certain action, and as tolerance develops more and more of the substance or the repetitive action is needed. Repetitive use of substance strengthens its effect and brings about sensitisation and a long period of failures when trying to give up the bad habit feels impossible. Withdrawal symptoms occur upon the sudden decrease in intake of substance or behaviour which had led to addiction. All addictive disorders are time wasters and those who are addicted spend an increasing amount of time to either feed their bad habit or trying to give it up. Finally, a tolerance to one drug also has a certain level to drugs belonging to the same class. This leads to cross dependencies.

The first most often sited possible causes of addiction (Füredi et al., 2015; Demetrovics \& Balázs, 2014) can be related to family history because those children whose parents are substance users are more susceptible to become addicts themselves. This cause of dependency can also be encouraged by conflicts between parents and children. The second factor feeding addiction is the negative impact of same-age groups especially in case of teenagers. The third factor is a special personality trait of those who suffer from addictive disorders. They often show signs of being risk-takers, looking for excitement or being rebellious against existing social realities.

It is generally true that various dependencies and addictions intensify each other. In the wake of addiction, there are broken relationships within families and circles of friends as well as broken careers. According to Németh et al. (1996) there is a 33 to 73 per cent correlation between gaming addiction and chemical addictions. Often, people living or working addicts assist unknowingly to the addiction to become stronger. A good example for this is the workaholic CEO who is considered a successful man by society. Buda Béla (1995) wrote in his book titled Ourpassions that in most cases there is nothing wrong with doing or using things occasionally which otherwise would be addictive. The impacts of addiction on economy, society and the individual are difficult to prioritise. 
Elvin Morton Jellinek was one of the ancestors of addictology who was the first to describe and create a curve of the various stages of alcoholism. In 1940 he had also participated in the foundation of the long-established scientific journal of addictology in the United States of America (Ward \& Bejarano, 2015). Today addictions are analysed from different aspects. The psychological model is focusing on the psychological injuries of the individual while the biological approach explains alcoholism as a disease. The moral model looks at how the society receives the behaviour of an alcoholic from a moral aspect and the criminal model finds the links between alcoholism and crime. There are two further models, the subculture model, and the spiritual model. The subculture model examines addictions as phenomena while the spiritual model believes that addicts use psychoactive substances to achieve a transcendent state of mind. All the different approaches focus only on one highly important aspect of addictions as a result it is safe to say that none of them can give a full explanation of dependencies.

We apply an economic approach to examine addictions, which integrates many of the factors described in the above-mentioned models. This way we can assess the damage, costs and/or benefit society, economy and individuals need to handle due to addictions.

There are many reasons why smoking is our chosen topic of interest. 'Currently, there are over a billion people all over the world who smoke daily.' Smoking as a harmful addiction causes the death of about 6 million people a year.' (Hungarian Society of Cardiology, 2015:1352). According to the latest available data from 2015 there are more than 10000 adolescents (between the ages 10 and 14) and 2.3 million adults (people over 15 year of age) smoke every day in Hungary (The Tobacco Atlas, n.d.). Between 1990 and 2017, 882 thousand people died in Hungary in connection with smoking (Portfolio.hu, 2019).

These numbers are much higher than the average numbers of high HDI countries (Human Development Index).

According to the data of EHIS 2014 Hungarian men are heavy smokers (number 8 on the list of countries) within the EU and women are the 3rd on the same list. Men in Cyprus are the most regular smokers and women in Austria smoke the most. Swedish men and Romanian women smoke the least frequently (Boros et al., 2018). 


\section{Creating the research model and applied methodology}

Our aim is to reveal the social and economic damages and benefits of producing and selling tobacco products. Related literature lists taxes collected from the tobacco industry as a primary benefit and the costs of various illnesses as primary costs of tobacco use. We assume that this approach simplifies issues related to the consumption of tobacco products. There are additional factors - both on the revenue side and on the cost side -, with economic and social impacts. Secondary research data collected from various sources have been used to validate these factors.

The Hungarian Economic Research Institute measured in 2004 the costs of smoking. Costs of hospital care, loss of income, disability payment, visits to the GP, loss of income tax payments, sick payment, and costs of medication are all factors used in the measurement. This issue had also been analysed by Bodrogi (2009), who claimed that smoking should be analysed as a highly complex social, economic, and cultural processes. According to Bodrogi this process has three main elements: (1) Government budget, (2) Healthcare system, (3) Tobacco industry. Vitrai (2012) also carried out an estimated cost analysis in relation to the direct and indirect costs of smoking and the state income from the tobacco industry in 2010. Compared to previous studies their analysis was more comprehensive.

Our study relies on existing data sources. Apart from collecting and categorising various data, we did some calculations and created a socioeconomic framework to identify the economic and social revenues and other benefits as well as costs related to smoking.

Table 1. Social and economic benefits and damages caused by smoking

\begin{tabular}{ll}
\hline \multicolumn{1}{c}{ Revenue } & \multicolumn{1}{c}{ Costs/Damages } \\
\hline & The costs of treating chronic \\
The added value created by companies & illnesses including possible \\
providing raw materials and producing & operations related to smoking. \\
tobacco products. It is also contributing to & $\begin{array}{l}\text { Deaths, rehabilitation programs } \\
\text { and maintaining the state of }\end{array}$ \\
GDP. & sobriety
\end{tabular}


Companies providing raw materials and producing, trading, and storing tobacco products create workplaces.

The increase in market demand created by those who are employed by companies providing raw materials and producing, trading, and storing tobacco products. Corporate and personal income tax as government budget revenue deriving from the producing, storing, and trading raw materials and tobacco products.

VAT and excise duty as government budget revenues resulting from purchasing tobacco products.

Health organizations being involved in the treatment of smoking related illnesses such as withdrawal symptoms and offering preventative programs also create workplaces.

The increase in market demand created by those who are employed by health organizations being involved in treatment of smoking related illnesses such as treating withdrawal symptoms and offering preventative programs.

Corporate and personal income tax as government budget revenues paid from the operation of health organizations being involved in treatment of smoking related illnesses such treating withdrawal symptoms and offering preventative programs.

Advertising, promotion

Supporting tobacco production
The amount of sick payment because of health damage.

Lost workdays because of health damage.

Cases of early death before retirement causes lost employment taxes and contributions to the government.

The financial and moral suffering of families.

Harm caused to second-hand smokers.

Accidents, cases of fire.

Pollution: cigarette butts, cigarette packages, etc. 
important to mention at this point that it had been challenging to reveal whether there are relationships between some of the variables. Moreover, there are also factors, which are difficult to quantify such as harm caused to families. As a result, clustering and comparing social and economic impacts are challenging. Consequently, we had not intended to quantify the economic profitability, or the welfare impacts of the tobacco industry as a whole. We aimed at finding the most recent data and research results. Despite not examining the methods of gaining these data, we believe that they provide a reliable source of information to demonstrate the various issues related to smoking in Hungary.

Table 1 includes all the factors, which either directly or indirectly contribute to all the revenues or other benefits as well as damages and costs generated by the tobacco industry.

\section{Revenues and benefits arising from tobacco production and consumption Tobacco industry and its contribution to GDP}

The income generated by the tobacco industry contributes to the GDP even though tobacco products are harmful to health and the illnesses caused by them lead to a decreasing quality of life. Also, companies operating across the tobacco industry use valuable resources from other potentially less harmful investments which could help people to increase their quality of life.

The value of growing tobacco in Hungary is a mere 0.002 per cent of the GDP. The revenues of the six largest tobacco companies worldwide had a revenue of USD 346 billion in 2016, which is 190 per cent more than the GDP of Hungary (The Tobacco Atlas, n.d.). Hungary produced 8000 tons of tobacco in 2015. In the same year, the tobacco production of Italy was 51407 tons, Spain 29361 tons, Greece 29140 tons and Poland 26222 (UNITAB Congress, 2016).

Table 2 shows the data provided by the Hungarian Central Statistical Office $\left(^{*}\right)$. According to that, the output of the tobacco production industry in Hungary decreased in 2014. It was followed by a period of stagnation and in terms of value it is slightly decreasing. According to the Hungarian Tobacco Growers' Association (**) the decrease of the quantity of production is in fact sharper, so the import of tobacco had more than doubled between 2014 and 2016. The increase of export had been slightly smaller than the increase in import but there is a decrease in net export. Although the downturn came to a halt in 2017, it resumed in 2018. 
Table 2. Tobacco growing in Hungary, import and export in tons and in HUF

\begin{tabular}{|c|c|c|c|c|c|c|c|c|}
\hline Year & $* 2014$ & *2015 & *2016 & ${ }^{* *} 2014$ & ${ }^{* *} 2015$ & ${ }^{* *} 2016$ & ***2017 & ****2018 \\
\hline $\begin{array}{l}\text { Harvested quantity } \\
\text { (tons) }\end{array}$ & 9459 & 7952 & 8012 & 9689 & 7447 & 6343 & 6802 & 5448 \\
\hline $\begin{array}{l}\text { Value of } \\
\text { production } \\
\text { (standard cost } \\
\text { price, in million } \\
\text { HUF) }\end{array}$ & 4228 & 3845 & 3326 & NA & NA & NA & NA & NA \\
\hline Import (tons) & 6473 & 8557 & 9587 & NA & NA & NA & NA & NA \\
\hline $\begin{array}{l}\text { Import value } \\
\text { (in million HUF) }\end{array}$ & 8279 & $\begin{array}{r}16 \\
419\end{array}$ & $\begin{array}{r}18 \\
148\end{array}$ & NA & NA & NA & NA & NA \\
\hline Export (tons) & 4667 & 4554 & 8507 & NA & NA & NA & NA & NA \\
\hline $\begin{array}{l}\text { Export value } \\
\text { (in million HUF) }\end{array}$ & 4866 & 4161 & 7591 & NA & NA & NA & NA & NA \\
\hline
\end{tabular}

\section{Direct and indirect employment in the tobacco industry}

Tobacco industry includes tobacco growing, tobacco fermentation and trading industries. The number of workers employed by these industries is significant. Statistical data from different periods show very different data because they used different methods.

According to a survey made in 2 000, there are more than 60000 workers employed by various industries related to tobacco growing and trade. Directly and indirectly, there are 140000 people employed by industries related to the consumption of tobacco products which means that about 15000 families or 5 000 full-time workers are employed there. Considering the tobacco industry there are some 3000 people employed in tobacco production and the wholesale of tobacco. The tobacco retail industry employs at least 120000 people, which is equal to the employment of 24000 full-time workers (Boros \& Bittner, 2004).

Table 3. The number of employees working in the tobacco industry in 2009

\begin{tabular}{llll}
\hline $\begin{array}{l}\text { Type of employment } \\
\text { (number of people) }\end{array}$ & Producers & Processing & Total \\
\hline number of employed & 2345 & 1407 & 3752 \\
Full-time & 224 & 1308 & 1532 \\
Seasonal & 2121 & 99 & 2220 \\
\hline
\end{tabular}

Source: Bittner, 2011 
Another survey from 2011 (Table 3) shows that there were about 4000 people employed in the total tobacco industry. These two statistics are contradictory because the number of workers according to the survey from 2011 is only 5 per cent of the number of people employed 10 years earlier considering only those working in the production sector.

Csipkés et al., (2017) estimated that the total number of working hours in the tobacco growing industry was 4709410 in 2014. If we consider that there had been 253 working days in 2014, the number of full-time workers in this industry was 18614 .

According to the latest data from 2017, the Hungarian tobacco growing industry employs around 10 to 12 thousand people. Most of the workers are women (approximately 70 per cent of the total number of workers) and 90 per cent of the total number of workers have no qualification at all. (NAK, 2020) Considering 12 thousand people employed it is about 0.003 per cent of the total number of people employed in Hungary.

The multiplier effect of workers' income spent should also be considered, but further estimates would lead to more inaccuracies. The same can be applied to demand. There is multiplicative effect of those working in the health industry and suffer from health issues because of smoking. They receive treatments and earn income at the same time.

\section{The contribution of the tobacco industry to the increase of the budget revenue}

The contribution of the tobacco industry to the increase of the budget revenue is defined as government revenue deriving from the direct and indirect taxes paid by growers, producers, and retail companies.

In the case of certain products not only VAT but also excise duty must be paid. Excise duty is a direct turnover tax, paid only once during the selling process. In Hungary, the present excise duty regulation was established after the World War II (Simon et al., 2006). After 1990, the number of tax evasions had increased dramatically because of strict tax laws leading to more comprehensive regulation which controlled the production and retail of excise products. It came into effect on June 1 1993. It. The main aim of the new law was to ensure government revenues, create a market environment of equal competition, put an end to black market activities and influence the consumption of harmful products. 
On November 41997 Act CIII took effect. Excise duty became a comprehensive tax to be paid after excise products.

After joining the European Union, the need for harmonisation of law made it necessary to pass Act CXXVII of 2003.

Today, excise duty includes two parts: itemized duty and value duty. The amount of itemized duty is calculated by using the price of 1000 cigarettes and the amount of value duty is calculated by using set percentage values of the retail price. The reason for this is to ensure that excise duty is adjusted to the market price of cigarettes.

Table 4. Excise duty revenues from tobacco product consumption

\begin{tabular}{llll}
\hline \multirow{2}{*}{ Years } & $\begin{array}{l}\text { Excise duty } \\
\text { (billion HUF) }\end{array}$ & Index & Chain \\
\cline { 3 - 4 } & 287.2 & $100.0 \%$ & $100.0 \%$ \\
2012 & 344.7 & $120.0 \%$ & $120.0 \%$ \\
2013 & 311.6 & $108.5 \%$ & $90.4 \%$ \\
2014 & 287.9 & $102.4 \%$ & $92.4 \%$ \\
2015 & 323.6 & $112.7 \%$ & $112.4 \%$ \\
2016 & 297.4 & $103.6 \%$ & $91.9 \%$ \\
2017 & 298.6 & $104.0 \%$ & $100.3 \%$ \\
2018 & 318.8 & $111,0 \%$ & $106,8 \%$ \\
2019 & 327.3 & $114,0 \%$ & $102,8 \%$ \\
\hline
\end{tabular}

Authors' own contribution. Source:

http://www.parlament.hu/irom40/05954/adatok/fejezetek/42.pdf http://www.parlament.hu/irom39/12002/adatok/fejezetek/42.pdf http://www.parlament.hu/irom40/12284/adatok/fejezetek/42.pdf http://www.parlament.hu/irom40/17578/adatok/fejezetek/42.pdf http://www.parlament.hu/irom40/10377/adatok/fejezetek/42.pdf https://www.parlament.hu/irom40/15381/adatok/fejezetek/42.pdf https://www.parlament.hu/irom41/00503/adatok/fejezetek/42.pdf

According to the most recent changes, excise duty on cigarettes and tobacco used for consumption is going to increase. The increase took place in two steps, the first in September 2018 and the second in January 2019 (Adozona, 2018).

Table 4 shows the changes in government revenues deriving from excise duty. Approximately 7 per cent of total tax revenue is provided by excise duty, and roughly a third of this comes from the (legal) consumption of tobacco products. 
Costs and damages caused by tobacco production and consumption of tobacco products

\section{Illnesses and deaths}

In Hungary there were around half a million patients treated in hospitals who had smoking related illnesses in 2010. It means that more than one third of the total number of patients (36 per cent), close to half of all male patients (46 per cent), and more than one quarter of all female patients were treated due to smoking. Also, in 2010, close to 440000 outpatients were treated. 45 per cent of the outpatients were male and 32 per cent of them were female (Vitrai, 2012).

According to international standards there are 15 diagnostic classification groups which are proven to be related to smoking (Vitrai, 2012). These are: trachea cancer, ischaemic heart disease, chronic obstructive lung disease, cancer of the upper digestive tract, cerebrovascular diseases, other cardiological diseases, pancreatic cancer, bladder cancer, kidney cancer, except for the renal pelvis, influenza and pneumonia, cervical cancer, other respiratory diseases deriving from the perinatal period, abnormalities related to premature birth and low birth weight, respiratory distress syndrome of newborn babies. There are some other sources quoting many more diseases related to smoking (The Tobacco Atlas, n.d.).

'In Hungary there were 28000 cases of death because of smoking ... This fact should arise an intense indignation and turn the attention of law makers to find solutions to reduce this number and smoking should be handled as a significant social issue... it damages consumers and their environment and causes huge health problems. It plays a significant part in the deaths of half of those who smoke.' (Bodrogi, 2009:45)

According to Vitrai (2012) 20470 people died from smoking related diseases in Hungary in 2010. It is 16 per cent of all deaths. In case of men close to 23 per cent of all deaths were due to smoking and in case of women it is 9 per cent of all deaths.

Wéber (2016) claims that between 2000 and 2014 there was a decrease of 13 per cent in excess mortality of men because of smoking. This number, in 2014 was 16754 . At the same time, excess mortalities among women increased by more than one third which is 7500 cases of deaths (Figure 1). Within one and a half decades, the number of men dying from nicotine addiction related diseases 
stagnated if we consider the total number of deaths but the number of women dying from nicotine addiction related diseases increased by 3.2 per cent. Every fourth death (27 per cent) was related to smoking in case of men and every 10th (12 per cent) death was related to smoking in case of women in 2014.

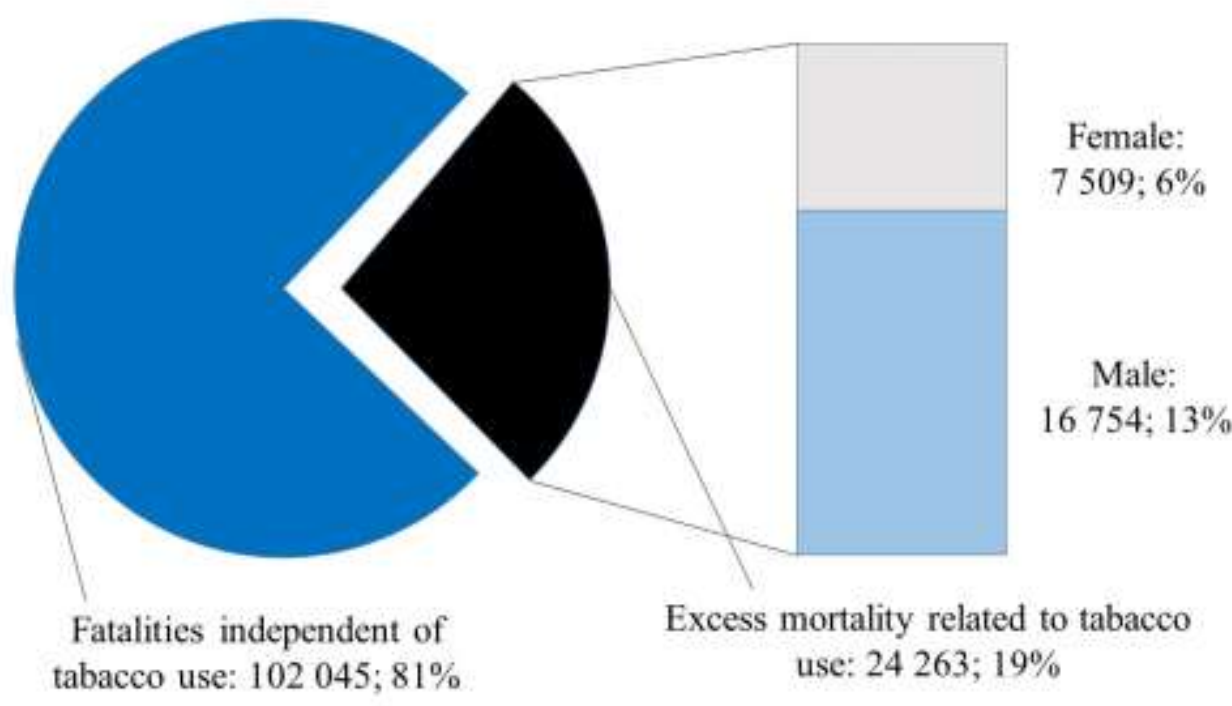

Figure 1. Excess mortality estimates based on the total number of deaths by gender, 2014

Source: Wéber (2016:595)

In 2017, the number of deaths related to smoking was 26081 in Hungary, and costs related to smoking was HUF 1567437 million. (The Tobacco Atlas, n.d.) This amount includes the direct and indirect costs of health expenditures, which are caused by early mortality and various smoking related diseases.

Smoking is the first on the EU list of avoidable health risks. Early mortality causes the deaths of about 700000 people. About 50 per cent of those who smoke, die early. Statistics show that smokers die 14 years earlier in average than nonsmokers. (European Commission, n.d.)

According to the 2008 estimates of the World Health Organization, 100 million people died from diseases related to smoking in the 20th century. The same research claims that in the 19th century the number of deaths due to smoking could have reached 1 billion. A report published by the medical officer of the US, smoking may shorten life expectancy by as long as 10 years (Peters et al., 2017). 
Isolating the social costs and benefits of smoking, the impacts of early deaths related to diseases caused by smoking on the health and pension expenditure is a great challenge. There have been some studies suggesting that both the health and pension expenditures are negatively affected by smoking related diseases. According to some other research, early deaths caused by smoking related diseases also have some positive effects. In a Phillip Morris research, it is claimed that the health and pension expenditures would be higher had it not been for those who die prematurely from smoking related diseases. In 2008, a Dutch study came to similar conclusions, healthy people are the costliest for the national health care system. The health costs of a Dutch citizen over 20 years of age are EUR 281000 annually as of 2003 whereas the health costs of a smoker are only EUR 22000 per year (van Baal, et al., 2008).

\section{Family}

Families that purchase tobacco products have less disposable income to buy other products and services, such as food or educational services. The most negative impact on families is that one fourth of smoking related deaths happens in the active years of smokers, which puts families in a financially difficult situation. Smoking related illnesses also cause loss of income because the patient might need an extended period to recover.

Based on GDP per capita in Hungary smokers must spend 5.84 per cent of their monthly income to have 10 cigarettes a day (The Tobacco Atlas, n.d.).

If we look at the family income status, we see different patterns of habit in case of male and female smokers. Male smokers smoke less as their income increases whereas the number of female smokers is increasing with increasing income. 4 per cent of males with the lowest levels of income smoke every day and 24 per cent of males with the highest levels of income smoke daily. For women, the greatest number of smokers can be found in the medium income group (26 per cent). Women with income under or above the average smoke less regularly although the women with the most income smoke the least frequently (15 per cent) (Boros et al., 2018). 
Table 5. Income spending on tobacco products per person in various income deciles (2015)

\begin{tabular}{cccc}
\hline $\begin{array}{c}\text { Income } \\
\text { deciles }\end{array}$ & $\begin{array}{c}\text { Gross income } \\
\text { (HUF/person) }\end{array}$ & $\begin{array}{c}\text { Net income } \\
\text { (HUF/person) }\end{array}$ & Forint / person / year 2 \\
\hline 1 & 371820 & 335949 & 12118 \\
2 & 664524 & 575285 & 19813 \\
3 & 911218 & 720163 & 19025 \\
4 & 1059166 & 863119 & 18798 \\
5 & 1266599 & 992874 & 21301 \\
6 & 1420655 & 1130070 & 17994 \\
7 & 1555127 & 1274162 & 20713 \\
8 & 1852818 & 1471227 & 24766 \\
9 & 2274772 & 1756280 & 22575 \\
10 & 3665620 & 2873038 & 25567 \\
Total & 1504048 & 1199094 & 20267 \\
\hline \multicolumn{4}{c}{ http://www.ksh.hu/docs/eng/xstadat/xstadat annual/i zhc021b.html } \\
http://www.ksh.hu/docs/hun/xstadat/xstadat eves/i zhc014a.html?down=1789
\end{tabular}

In the amounts spent on tobacco products in various income deciles, we cannot find strong connection between income and income spent on smoking. The last 3 deciles are exceptions where income spent on tobacco products is the highest per person (in order: $9,8,10$ ), and the income spent on tobacco products is the lowest in the first deciles (Table 5).

A person who smokes 20 cigarettes a day spends between HUF 401500 and 438 000 per year. This amount could be spent on valuable food items such as 1700 litres of milk or $1150 \mathrm{~kg}$ of oranges.

\section{Lost workdays and the amount of sick payments as a result of health damage}

Based on data provided by the GKI Economic Research Co. Bodrogi (2009) suggested in a study that the costs of smoking in Hungary were between HUF 148.5 and 152.9 billion. The estimate includes a loss of income between HUF 27.5 and 28.5 billion.

According to another research smokers fall ill more often. They have an average of 2.7 days more sick days than non-smokers. As a result of that there is about HUF 100 billion loss of income every year. Smokers also cause financial loss to their employers because in average they work 50 to 60 minutes less because of 
their smoking habit. Sick payments cost an estimated HUF 6 billion for the health care system. Employers also need to pay one quarter of sick payment and all the other allowances that employees are entitled to during sick leave (Gábris, 2015).

\section{Damages caused to second-hand smokers}

Second-hand smoking (SHS) or environmental tobacco smoke (ETS) damage can make an impact in two different ways. There is the so-called main smoke exhaled by the smoker and the side smoke leaving the lit cigarette, cigar, or pipe.

The following facts were reported in a Hungarian study:

- Two thirds (66 per cent) of smokers smoke in their own homes. 12 per cent of non-smokers are forced to inhale cigarette smoke at home.

- The prevalence to smoke at workplaces or inside bars is around 7 per cent among non-smokers. 5 per cent of these had experienced cigarette smoke in waiting rooms as well.

- 10 per cent of non-smokers experienced tobacco smoke more often at open-air places than at inside places. One fifth of non-smokers (21 per cent) were exposed to tobacco smoke at public transport waiting areas (Vitrai, 2012).

According to a report published by the EU the protection of second-hand smokers put them in a better position by 2013 than before. 46 per cent of nonsmokers were exposed to smoke in inside bars in 2009 whereas in 2012 this figure was only 28 per cent. Second-hand smoking is a great contributing factor of mortality, morbidity, and disability. According to some estimation in 2002 more than 70000 people died because of being exposed to second-hand smoking. Many of these deaths were caused by inhaling smoke at workplaces (European Commission, 2013).

As global data indicates second-hand smoke kills close to 900000 people every year. Young people are especially vulnerable inside and outside of homes. Figure 2 shows the estimated prevalence of youth aged between 13 and 15 inside bars. That is about half of all young people within this age group. Young people in Europe are in the worst position because three quarters of them are exposed to smoke indirectly in open areas (Drope, 2018).

According to the research results of Global Youth Tobacco Survey in 2019-2020, young people between the ages 13 and 15 in Hungary can be characterised by the following 
(Fókuszpont, 2020): 17 per cent of the young people are exposed to cigarette smoke in their own home; 34 per cent are exposed to cigarette smoke outside their home; 85 per cent of young people are non-smokers; 32.5 per cent has tried smoking; 35 per cent smokes at home; 40 per cent of them has at least one parent who is a smoker.

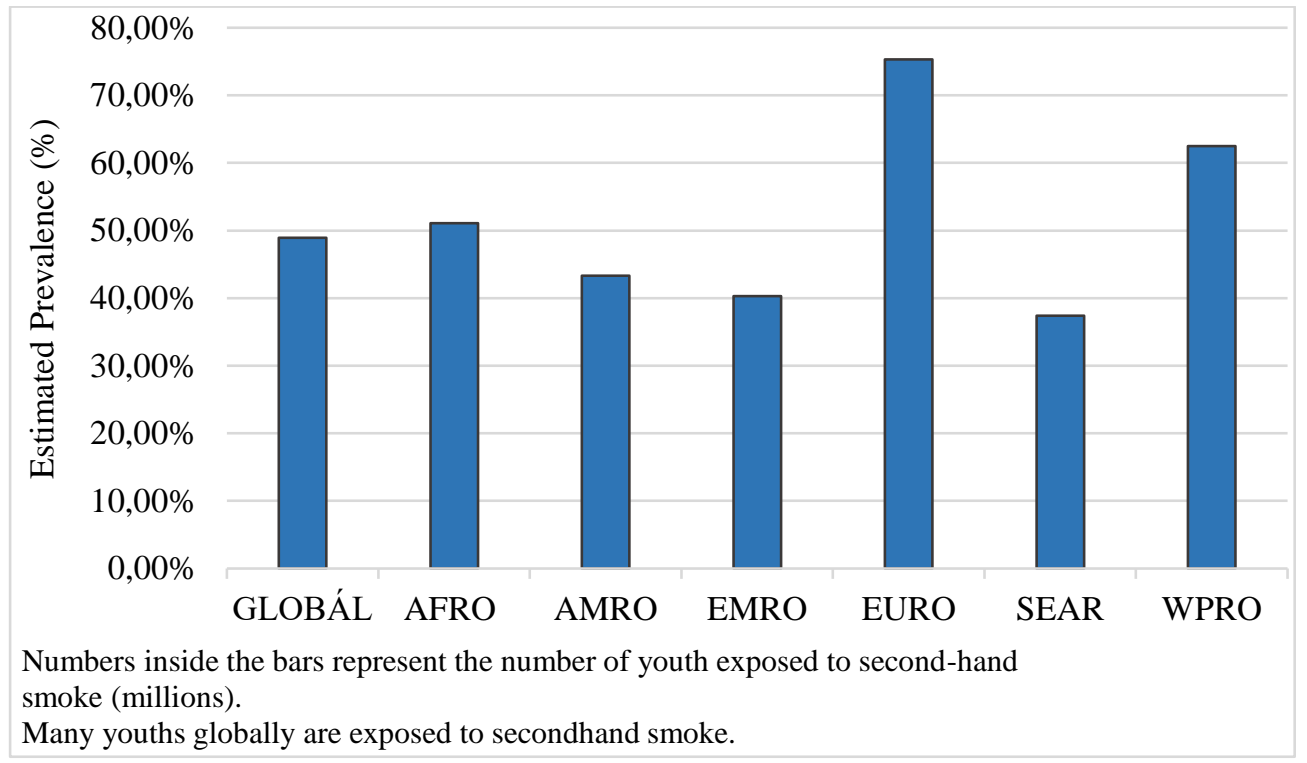

Figure 2. Prevalence in Youth. Percentage and number of youths exposed to second-hand smoke outside their home by WHO Region, ages 13-15, 2007-2014

\section{Source: https://tobaccoatlas.org/topic/secondhand/}

\section{Accidents and cases of fire}

Fire is most often caused by open flames such as candles, electronic devices generating heat and smoking.

According to research every sixth cases of fire death were caused by smoking in 2006. Table 6 shows the number of fires caused by smoking or cases of fires suspected to be caused by smoking. Until 2006 the number of such cases was decreasing.

Another research suggests that 19 out of 65 cases of fire ( 30 per cent) were caused by smoking (Bérczi \& Pócsik, 2017).

It is important to emphasise that to estimate the number of fire cases related to smoking is not easy because in most cases there is no fire test procedure. Last year there were only 1000 proven cases of fire out of 21054 cases. Fire test 
procedure is only carried out in fatal fire cases, crime cases or if fire breaks out in an apartment building (Sárosy, 2016).

Table 6. Cases of fire and their link to smoking

\begin{tabular}{llllll}
\hline Year & \multicolumn{2}{l}{ Fire caused by smoking } & \multicolumn{2}{l}{$\begin{array}{l}\text { Suspected fire cases } \\
\text { caused by smoking }\end{array}$} & $\begin{array}{l}\text { All cases } \\
\text { of fire }\end{array}$ \\
\hline 1998 & 917 & $3.02 \%$ & 3379 & $11.11 \%$ & 30411 \\
1999 & 463 & $2.53 \%$ & 1671 & $9.15 \%$ & 18268 \\
2000 & 868 & $2.61 \%$ & 3092 & $9.31 \%$ & 33194 \\
2001 & 492 & $1.99 \%$ & 1695 & $6.85 \%$ & 24749 \\
2002 & 524 & $1.66 \%$ & 1912 & $6.06 \%$ & 31541 \\
2003 & 489 & $1.57 \%$ & 1781 & $5.73 \%$ & 31090 \\
2004 & 355 & $1.65 \%$ & 917 & $4.27 \%$ & 21471 \\
2005 & 317 & $1.28 \%$ & 1085 & $4.38 \%$ & 24748 \\
2006 & $961 *$ & $4.40 \%$ & $62 *$ & $0.28 \%$ & 21829 \\
\hline
\end{tabular}

Source: http://www.vedelem.hu/letoltes/anyagok/688-a-dohanyzas-szerepe-atuzesetekben.pdf

According to available data there were approximately 30000 fire cases related to smoking in the EU between 2003 and 2008. The number of fatalities in these cases are over 1000 and the number of injuries is over 4000 . It is also proven that after the introduction of lower ignition propensity cigarettes the fatalities have decreased by 40 per cent. These are cigarettes which are self-extinguishing and are safer. This safety measure was introduced in some countries such as the USA, Canada, and Australia. Since April 2010 it was also introduced in some EU countries such as Finland (European Commission, 2011).

\section{Pollution: cigarette butts and packages}

Thirdhand smoke (THS) refers to residual tobacco smoke constituents that remain on surfaces such as curtains or carpets and in dust after tobacco has been smoked. These residual constituents include harmful elements of cigarette smoke. Cigarette butts contain chemical compounds such as nicotine, benzylamine, various toxic gases and radioactive elements such as polonium.

Cigarette butts are the most common waste items in the world. According to some estimates there are some

700000 tons of toxic waste in Hungary each year. (ecolounge.hu, 2016) As reported by an international study 25 to 50 per cent of street rubbish is cigarette 
butts, which is especially dangerous for aquatic organisms. 5.6 billion cigarette butts are thrown each year. It would fill 375 rail wagons. (Egeszseg, n.d.)

\section{Costs and revenues of other factors}

\section{Advertising}

As the view on smoking has shifted the demand to control tobacco advertising and sponsorship has increased. It had to be determined which areas tobacco products could not be advertised. It is a hugely effective way of reducing demand for tobacco products. One of the most important regulations in relation to the tobacco industry is Act XLVIII of 2008 (Act on Advertising) which prohibited both the direct and indirect advertisements of tobacco products. For many years tobacco companies acted as sponsors of major sporting and cultural events such as Formula 1. The 2008 Act on Advertising and the Act CLXXXV of 2010 on Media Services and Mass Communication prohibited the direct or indirect advertising and sponsorship of tobacco companies on sport, cultural, health or political events.

Despite the strict regulation, 4 out of 10 voters claimed in 2014 that they had seen some sort of tobacco advertisement or promotion. The most common place for them was points of sales (39 per cent) and billboards (30 per cent) (European Commission, 2015). A study in 2016 focused on adolescents between the age of 13 and 15 (Fókuszpont, 2020). Almost half of the respondents (37 per cent) said that they saw anti-smoking advertisement on TV, on message boards (22 per cent), in newspapers or magazines (16 per cent), on the Internet (47 per cent) own a promotional product $(7$ per cent).

These initiatives aim at protecting public health from the dangers related to smoking and second-hand smoke. All initiatives are concerned with the tobacco use of young people because 94 per cent of smokers become addicted to smoking before the age of 25 .

Current study is not dealing with all national and international policies to control tobacco use.

It is also important to acknowledge that the prohibition of tobacco advertising withdraws many potential clients. This also means a loss of revenue for advertising companies. Multiplier effect is also important since those working in the advertising industry increase revenues elsewhere. The Hungarian advertising industry is nevertheless continually increasing. In 2016 there was an 11.9 per cent 
increase compared to the year before and in 2017 the growth of the advertising industry was 11.52 per cent (Szalay, 2018).

\section{Subsidising tobacco growers}

As EU support stopped in 2015 the Hungarian government provides support for the tobacco growing industry which requires many workers. According to the 53/2015. (IX. 14.) FM decree (Ministry for Agriculture) regulates the 'National Restructuring Plan for tobacco and the conditions of the granting of small amounts of grants'. The aim of the national restructuring plan is to provide support for tobacco growers in order to ensure that agricultural land considered for the purpose of determining the reference area shall not be extracted from the agricultural use; tobacco growers maintain the employment level of workers who had previously worked for the industry throughout the duration of the participation of the tobacco grower in the restructuring plan (53/2015:1959219593).

In relation to the statute the Under Secretary of Agriculture stated: „There is no industry today in Hungary which would receive such high amount of subsidy and help to stay on the market in a competitive state" $(24,2017)$.

The national agricultural subsidy provides a total of HUF 3.5 billion which means that every farmer is entitled to receive a minimum of HUF 620000 . The subsidy also includes HUF 1.5 billion which is tied to product output. Tobacco growers received around HUF 900000 per hectare in 2016.

\section{CONCLUSIONS}

Over the course of our investigation, finding up-to-date statistical data regarding the social and economic impacts of smoking was challenging and, in some cases, we failed to find any. Nevertheless, we believe that data from recent years are equally useful in the sense that they can highlight areas of concern.

Up-to-date data relevant to the analysis of the social and economic impacts of smoking was insufficient. Even so, relying on recent data is still reliable enough to highlight major areas of concern.

There are several interest groups on both sides of the scale measuring the benefits and costs of smoking. In the last few years, it seems that anti-smoking campaigners are winning. 


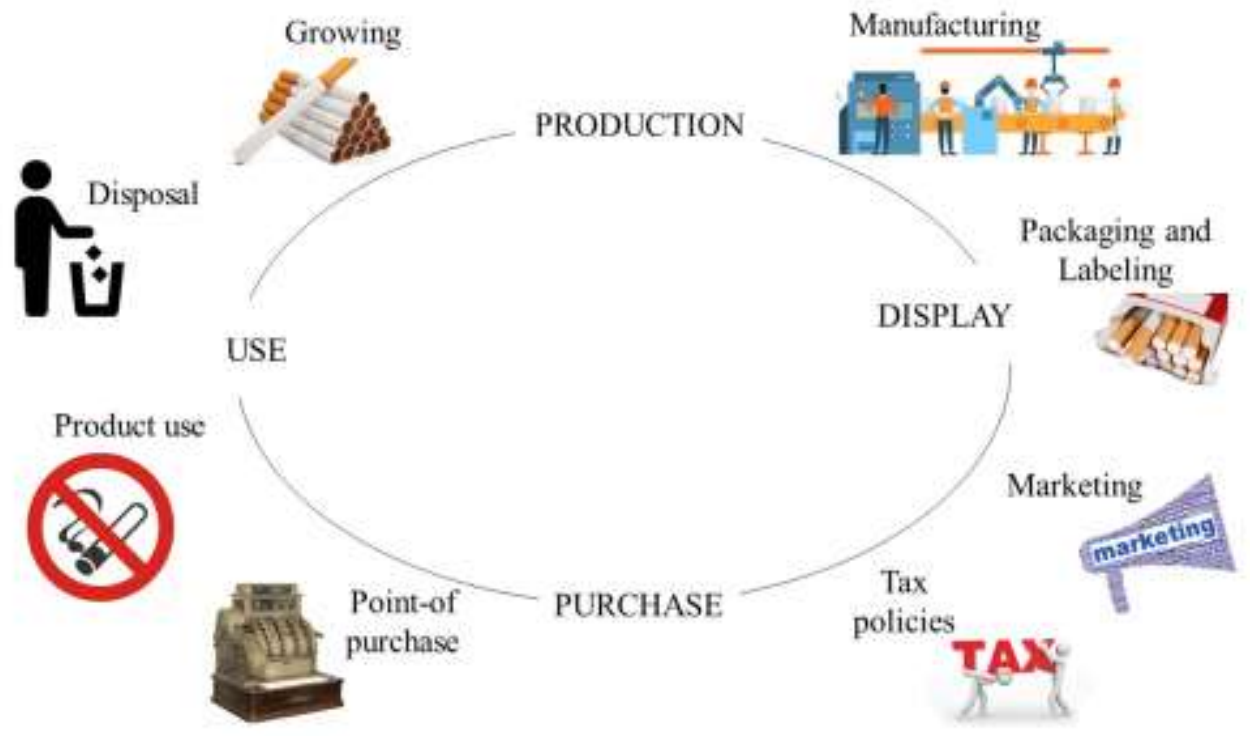

Figure 3. Wheel of Tobacco Regulation

Authors' own contribution. Source: https://tobaccoatlas.org/mission/

In relation to controlling smoking the cooperation of many participants and many related areas are involved (Figure 3).

- Growing: Governments must help to improve supply and value chains for alternatives to tobacco leaf and invest in farmer's education/retraining program.

- Manufacturing: Ban all tobacco additives including flavourings.

- Packing and Labelling: Plain, standardized packaging of all tobacco products.

- Marketing: Ban all direct and indirect forms of marketing, including advertising, promotion, and sponsorship.

- Tax Policies: Implement higher excise taxes on all tobacco products and make certain that increases outpace inflation and income growth.

- Point-of-Purchase: Eliminate all signs and even hints of tobacco product sales, including keeping them out of sight behind the counter.

- Product Use: policies should make all indoor, workplace ad public outdoor spaces smoke-free, and find effective, new ways to keep smokers from smoking in their homes with non-smokers.

- Disposal: Get the tobacco industry to bear the cost of cleaning up the environmental devastation from the waste left by tobacco production and use. 
In the last few years there have been major improvement in the regulation of tobacco use in Hungary, but further regulations are needed. This need is supported by statistics from 2010, which shows that the Hungarian population had been wasted close to 600000 healthy years because of smoking. This means that we are the last among EU countries (Alpár et al., 2016).

Smoking control is a complex task because many participants need to work together to find solutions. To have sufficient results international cooperation need to be effective on all three levels (individual, corporate and state) and all areas show on Figure 3.

The conscious participation of the individual is unavoidable. Individuals must take responsibility for themselves and those living close to them by giving up smoking.

Corporations are also in a difficult position because it is still challenging to reconcile profit maximization and social responsibility. Moreover, social responsibility initiatives are less authentic when they come from companies operating in the tobacco industry.

The tobacco industry often claims that it provides many workplaces but in most national economies tobacco production takes up only a small part of the economy. If there were more initiatives to discourage smoking more workplaces would be created in other industries and consumers would spend parts of their disposable income elsewhere (World Bank, 2001).

The role of media can be mentioned at the macro level since mass media provides valuable information about the impacts of smoking, draws the attention to important publications and it can influence social norms in a positive direction (Tompa, 2003).

State level. Governments can introduce effective anti-smoking policies, which lead to a decrease in the number of smokers. It has a positive impact on individual and social well-being. But the government is in a difficult position if they set themselves the task of improving the position of all participants of the economy. There has been an increase in regulation to control tobacco use in Hungary including advertising bans, excise increases, smoke-free dining along with strictly designated smoking areas and graphic health warnings on packaging in. In 2012 the Hungarian government made the sale of tobacco products a state monopoly by establishing national tobacco shops and running them as concessions. While there are many policy changes to support the discouragement of smoking, 
tobacco growing is also heavily subsidised which weakens the effects of antismoking policies.

Governments are often hesitant of raising taxes because it causes a decrease in the market demand. The degree by which market demand decreases is smaller than the increase of prices because cigarettes are highly inelastic (World Bank, 2001).

The number of smokers in Hungary has not decreased since the sale of tobacco products became state monopoly in Hungary. Instead, the number of those who smoke rolled up cigarettes has increased dramatically and also the size of the black market for cigarettes has increased.

International level. The European Union has an international role in controlling the use of tobacco. It had a significant part in the development of the Framework Convention on Tobacco Control which entered into force on February 2, 2005. This framework is the first binding convention of the World Health Organization. The core demands of the framework include non-price measures to reduce the demand to tobacco such as packaging and labelling of tobacco products, tobacco advertising, promotion and sponsorship, protection from exposure to tobacco smoke, illicit trade in tobacco products, pricing and taxing tobacco products and offering economically viable alternatives for tobacco growers. (European Commission, 2011)

Policies and initiatives related to tobacco control also have social and economic benefits as well as costs similarly to many other factors that we analysed at the beginning of this study (Table 1). Benefits are quite straightforward if we can save lives, or there would be less smoking related illnesses and lower health costs. But all policies and other initiatives require major financial investments which need to be withdrawn from other areas such as education or culture. Obviously spending money on the fight against tobacco is worthwhile because it might change the future outlook of many people but there will always be trade-offs. Prevention would be the most cost effective solution if we didn't spare any expenses because helping people give up smoking and reducing the costs of treating diseases related to tobacco would bring the most benefits to the society as a whole. 


\section{REFERENCES}

1. 24.hu (2017): https://24.hu/fn/gazdasag/2017/09/08/atlagon-felul-tamogatjaa-kormany-a-dohanytermesztoket/ (2020.11.19.)

2. Adozona.hu (2018.):

https://adozona.hu/2018 as valtozasok/Novelnek a cigaretta adojat szigori tanak a NEM9DI (02.10.2020.)

3. ALPÁR, Á., BALKU, E., BERKI, J., DEMJÉN, T., KIMMEL, Zs., KISS, J., KOVÁCS, G., TALLER, A. \& VARSÁNYI, P. (2016): Dohányzás visszaszorítása.

4. BALZAC, Honoré de (1955): Ferragus. Budapest: Szépirodalmi Könyvkiadó.

For the English translation:

http://103.38.225.178:8090/EBOOK 06/EBOOK 0654900.pdf p. 27.

5. BÉRCZI, L. \& PÓCSIK, A. (2017): Halálos áldozatot követelő tűzesetek elemzése. Katasztrófavédelmi Szemle 24(3): 29-31.

6. BITTNER, B. (2011): A dohányvertikum gazdasági, társadalmi hatásának vizsgálata. Debrecen: PhD.

7. BODROGI, J. (2009): A dohányzás makrogazdasági összefüggései. IME Interdiszciplináris Magyar Egészségügy, 8(5): 45-48.

8. BOROS, J., GYORKE, J. \& PASZTORNE Stokker, E. (2018): A 2014-ben végrehajtott Európai lakossági egészségfelmérés eredményei. Összefoglaló adatok. Budapest: Központi Statisztikai Hivatal.

9. BORSOS, J. \& BITTNER, B. (2004): Fenntartható-e a dohánytermelő körzetekben az ágazat fejlődése? Gazdálkodás, 48(4): 28-34

10. BUDA, B. (1995): Szenvedélyeink. Budapest: SubRosa Kiadó.

11. CSIPKÉS, M., SZVÁRA M. \& NAGY, L. (2017): Magyarország dohányvertikumának bemutatása az elmúlt 10 évben. Jorunal of Central European Green Innovation 5(1): 80-103.

12. DEMETROVICS, Zs. \& BALÁZS, H. (2004): Drogosok. In Gelsei, G., Gergely, V., Horváth V. \& Rácz M. M. (eds) A láthatatlanság vége társadalomismereti olvasókönyv. Budapest: Alapítvány a társadalomelméleti Kollégiumért. 121-141.

13. DROPE J., SCHLUGER, N., CAHN, Z., DROPE, J., HAMILL, S., ISLAMI, F., LIBER, A., NARGIS N. \& STOKLOSA, M. (2018): The Tobacco Atlas. Atlanta: American Cancer Society and Vital Strategies. From: https://tobaccoatlas.org/wpcontent/uploads/2018/03/TobaccoAtlas 6thEdition_LoRes_Rev0318.pdf (14.04.2018.)

14. Ecolounge.hu (2016). http://ecolounge.hu/eletmod/kozel-hetszazezer-tonnaveszelyes-hulladek-keletkezik-evente-magyarorszagon (20.10.2020.)

15. Egészség (2020). http://egeszseg.hu/-/375-vagon-szemet-tobb-szaz-lakastuzmilyen-karokat-okozhat-egy-eldobott-csikk (12.11.2020.) 
16. European Commission n.a.

https://ec.europa.eu/health/tobacco/overview_hu (2018.10.02.)

17. European Commission

:https:/ /ec.europa.eu/commission/presscorner/detail/hu/MEMO_11_349

(2020.12.03.)

18. European Commission (2015).

From:https://ec.europa.eu/commission/presscorner/detail/hu/IP $15 \quad 5028$ (2020.12.03.)

19. European Commission (2011). Fogyasztók: egy új uniós intézkedésnek köszönhetően csökkenni fog a cigaretta okozta tűzesetek száma, és évente több száz ember élete lesz megmenthető Sajtóközlemény: From: http://europa.eu/rapid/press-release IP-11-1342 hu.htm (20.05.2018.)

20. Európai Bizottság (2013). Dohányzási szokások az. EU-ban: a Bizottság jelentése alapján csökkeknt, de továbbra is magas fokú a passziv dohányzásnak való kitettség. Sajtóközlemény. From: http://europa.eu/rapid/press-release IP-13147 hu.htm (20-05-2018)

21. FENYVESI, É. \& KAJÁRI, K., 2016. A dohányzás okozta társadalmi, gazdasági problémák. In Fenyvesi, É. \& Vágány, J. (szerk) Korkép. XXI. századi kibivások. Budapest: Budapesti Gazdasági 41-67. https://www.researchgate.net/publication/304828014 A dohanyzas okozta tarsadalmi gazdasagi problemak $(01.07 .2020)$

22. Fókuszpont (2020): Magyarországi Ifjúsági Dohányzás Felmérés. From: https://fokuszpont.dohanyzasvisszaszoritasa.hu/hu/content/hazai-eskulfoldi-adatok-tanulmanyok (02.12.2020)

23. FÜREDI, J., NÉMETH, A. \& TARISKA, P. (2015). (szerk.): A Pszichiátria Magyar Kézikönyve Budapest: Medicina Könyvkiadó Zrt.

24. GÁBRIS, E. (2015): A dobányzás gazdasági hatásai. https://index.hu/leszokik/2015/04/02/a dohanyzas gazdasagi_hatasai/ (25.05.2018.)

25. Magyar Kardiológusok Társasága (2015): A dohányzás még hazánkban mindig dobogós helyen. Élet és Tudomány, 70(48): 1532.

26. NAK (2020). https://www.nak.hu/agazati-hirek/mezogazdasag/146novenytermesztes/94882-biztos-munkat-jelent-a-dohanytermesztes (12.11.2020.)

27. NEMESKÉRI, Zs. \& PANKÁSZ, B., 2015. (eds) Módsz̧ertani Kézikönyv. Pszichés zavarok felismerése és kezelése a munkahelyen. Pécs: Pécsi Tudományegyetem Felnőttképzési és Emberi Erőforrás Fejlesztési Kar 35-36. 
28. NÉMETH, A., LUKÁCS, E., MÓROTZ, K., TREUER, T., VANDLIK, E. \& BONCZ, I. (1996): Kóros játékszenvedély-12 beteg adatainak feldolgozása alapján. Psychiatria Hungarica 11(5): 534-546.

29. PETERS, F., MACKENBACH, J. \& NUSSELDER, W. (2017): Kell-e számolniuk az élettartam-előrejelzéseknek a dohányzás hatásával? Statisz̨tikai Szemle 95 (5): 536-538. https://doi.org/10.20311/stat2016.06.hu0585

30. Portfolio (2019): https://www.portfolio.hu/gazdasag/20190208/a-karosszenvedely-amibe-mar-majdnem-egymillio-ember-halt-bele-magyarorszagon$\underline{313247 \#}$

31. SÁROSY, M. (2016): Megdöbbentő, mi okozza a tűzesetek több mint harmadát! https://ripost.hu/cikk-megdobbento-mi-okozza-a-tuzesetek-tobb-mintharmadat (15.08.2020)

32. SIMON Z., POZSGAI, Z., KIS, J. \& BOROS, S. (2006): Jövedéki alapok I. és II. Budapest: Lónyay Menyhért Szakkönyvtár, VIVA Média Holding Kiadó.

33. SZALAY, D. (2018): Reklámtorta 2017. Magyar Reklámszövetség. Prezentáció. From: https://www.slideshare.net/prezista/mrsz-reklamtorta-2017180228 (15.04.2018.)

34. UNITAB Congress, (2016). http://madosz.hu/storage/kcfupload/files/Eislerj\%C3\%B3zsef/Cikkek/2016-SOFIA--UNITABdiapoFV.pdf (10.09.2020.)

35. The Tobacco Atlas, n.d. https://files.tobaccoatlas.org/wpcontent/uploads/pdf/hungary-country-facts-en.pdf (20.10.2020.)

36. TOMPA, A. (2003): Egészségtudat és tudatos egészség. http://mindentudas.hu/el $\% \mathrm{C} 5 \% 91 \mathrm{ad} \% \mathrm{C} 3 \% \mathrm{~A} 1$ sok $/$ tudom $\% \mathrm{C} 3 \% \mathrm{~A} 1$ nyter $\% \mathrm{C}$ 3\%BCletek/orvostudom $\% \mathrm{C} 3 \% \mathrm{~A} 1 \mathrm{ny} / 122$ eg $\%$ C3\%A9szs $\%$ C3\%A9gtudom $\%$ C3\%A1 nyok $/ 6068$-egeszsegtudat-estudatos-egeszseg.html (04-03-2018).

37. VAN BAAL, P.H., POLDER, J.J., ARDINE DE WIT, G., HOOGENVEEN, R.T., FEENSTRA, T.L., BOSHUIZEN, H.C., ENGELFRIET, P.M. \& BROUWER W.B.F. (2008): Lifetime Medical Costs of Obesity: Prevention No Cure for Increasing Health Expenditure. https://doi.org/10.1371/journal.pmed.0050029

38. Világbank (2001): A világméretü járvány megfékezése. A kormányzatok szerepe és a dohányellenörzés gazdaságtana. https://mek.oszk.hu/08000/08082/08082.pdf

39. VITRAI, J. (2012) (ed.): A dohányzás társadalmi terhei Magyarországon. Országos Egészségfejlesztési Intézet. https://docplayer.hu/3331194-A-dohanyzastarsadalmi-terhei-magyarorszagon.html (10.06.2018.)

40. WARD, H.J. \& BEJARANO, W. (2015): Az addikciótudomány történetéből: E. M. Jellinek. Orvosi Könyvtárak - Medical Libraries, 12(1): 13-28. 
41. WÉBER, A. (2016): A dohányzás halandóságra gyakorolt hatása Magyarországon 2000 és $2014 \quad$ között. Statisz̧tikai Szemle, 94(6): 585-610. https://doi.org/10.20311/stat2016.06.hu0585

42. 53/2015. (IX. 14.) FM rendelet a dohány szerkezetátalakítási nemzeti programról és az azzal összefüggésben igényelhetô csekély összegú támogatások feltételeinek megállapításáról. Elérhető: http://www.madosz.hu/storage/kcfupload/files/Eislerj\%C3\%B3zsef/Rendeletek/Magyar-Kozlony-127Dohanytamogatasa.pdf (2021.01.01) 
ISSN 2630-886X

18 国 57
BGE 